Web Jurnal:

http://ejournal.kemenperin.go.id/jli

\title{
Pengaruh jenis isolat-isolat bakteri fermentatif dari ubi kayu terhadap rendemen, derajat putih, dan bentuk granula tepung mocaf
}

\section{Effect of fermentative bacterial isolates from cassava on yield, white degree and shape of mocaf flour granules}

K Kamsina*1, N Nurmiati ${ }^{2}$, dan P Periadnadi ${ }^{2}$

1 Balai Riset dan Standardisasi Industri Padang

Jl. Raya LIK No. 23 Ulu Gadut, Padang, Indonesia

2 Jurusan Biologi Fakultas Matematika dan Ilmu Pengetahuan Alam, Universitas Andalas

Kampus Limau Manis, Padang, Indonesia

*kamsinaina@gmail.com

\begin{tabular}{l}
\hline INFO ARTIKEL \\
\hline Sejarah artikel: \\
Diterima: \\
15 Oktober 2019 \\
Direvisi: \\
18 Desember 2019 \\
Diterbitkan: \\
30 Desember 2019
\end{tabular}

\section{Kata kunci:}

isolat;

tepung mocaf;

ubi kayu

\begin{abstract}
ABSTRAK
Isolat bakteri indigenous ubi kayu merupakan isolat bakteri asli yang berada dalam umbi ubi kayu. Ubi kayu jenis lambau dan ketan (Manihot esculenta Crantz) merupakan jenis ubi kayu lokal Sumatera Barat, sedangkan ubi kayu kultivar karet (Manihot glaziovii) merupakan ubi kayu dengan kandungan asam sianida (HCN) tinggi. Penelitian ini bertujuan untuk melihat kemampuan masing-masing isolat bakteri indigenous ubi kayu terhadap rendemen, derajat putih serta bentuk granula tepung mocaf yang dibandingkan dengan perlakuan tanpa pemberian isolat. Penelitian menggunakan rancangan acak lengkap (RAL) dengan perlakuan pemberian starter isolat bakteri indigenous ubi kayu jenis ketan (A), lambau (B), karet (C) dan tanpa isolat/kontrol (D). Terhadap produk mocaf yang dihasilkan dilakukan pengujian meliputi rendemen, derajat putih, dan bentuk granula tepung mocaf. Hasil analisis terhadap berbagai perlakuan menunjukkan perlakuan optimal untuk tepung mocaf yang dihasilkan adalah pemberian starter isolat bakteri indigenous jenis ketan dengan rendemen 35,85\%, derajat putih 94,40\% dengan dinding sel ubi kayu sudah banyak yang pecah menjadi granula-granula yang lebih kecil dan memiliki rongga pada bagian granulanya.
\end{abstract}

\begin{abstract}
Cassava indigenous bacterial isolates are native bacterial isolates that are in tubers of cassava. Lambau and sticky rice (Manihot esculenta Crantz) are types of local cassava from West Sumatra, while rubber cultivar cassava (Manihot glaziovii) is a cassava with a high content of cyanide acid (HCN). This study was aimed to look at the ability of each indigenous cassava isolate to yield, the degree of white and the form of mocaf flour granules compared to the treatment without administration of isolates. The study used a completely randomized design (CRD) with the following treatments: administration of indigenous cassava isolate starter of sticky rice type (A), lambau (B), rubber $(C)$ and without isolate / control (D). The mocaf products were tested including yields, white degrees, and the granules shape of mocaf flour. The analysis results of various treatments showed that the optimal treatment for mocafflour produced was the provision of indigenous bacterial isolates starter from sticky rice type (A) with a yield of $35.85 \%$, white degree $94.40 \%$ with a lot of cassava cell walls that had broken into smaller granules and had cavities on the granules.
\end{abstract}

(C) 2019 Penulis. Dipublikasikan oleh Baristand Industri Padang. Akses terbuka dibawah lisensi CC BY-NC-SA

\section{Pendahuluan}

Ubi kayu merupakan komoditi yang digalakkan untuk diversifikasi pangan pengganti beras dan menyumbang ekspor terbesar bagi sektor pertanian di Indonesia. Di Sumatera Barat ubi kayu termasuk komoditi unggulan dengan produksi tahun 2018 sebanyak 184.369 ton (BPS Sumatera Barat, 2018). 
Selain dimanfaatkan sebagai bahan pangan pokok utama, ubi kayu juga diproduksi sebagai makanan cemilan seperti kripik atau sanjai, godok ubi, delima, krupuk ubi atau krupuk kamang, lapek, dan sebagainya. Di Sumatera Barat sendiri banyak UMKM yang menjual produk olahan makanan berbasis ubi kayu. (Saliem and Nuryanti, 2011).

Kandungan kimia dan gizi dalam 100 g umbi ubi kayu adalah protein $8,11 \mathrm{~g}$; serat kasar 15,20 g; pektin $0,22 \mathrm{~g}$; lemak 1,29 g; kalsium 0,63 g. Sedangkan komponen kimia dan gizi daging singkong dalam $100 \mathrm{~g}$ adalah protein $1 \mathrm{~g}$; kalori $154 \mathrm{~g}$; karbohidrat $36,8 \mathrm{~g}$; lemak 0,1 g (Rukmana, 1977 dalam (Putri and Hersoelistyorini, 2012). Mengingat tingginya kandungan karbohidrat (pati) pada ubi kayu, maka ubi ini dapat dimodifikasi menjadi tepung mocaf.

Mocaf merupakan singkatan dari modified cassava flour yang berarti tepung singkong yang dimodifikasi. Tepung ini memiliki sifat yang mirip dengan tepung terigu, namun kandungan proteinnya lebih rendah, Mocaf secara definitif adalah produk tepung dari ubi kayu yang diproses dengan prinsip memodifikasi sel ubi kayu secara fermentasi, menggunakan mikroba bakteri asam laktat atau BAL mendominasi selama fermentasi tepung ubi kayu ini. Mikroba BAL ini menghasilkan enzim pektinolitik dan sellulolitik yang dapat menghancurkan dinding sel ubi kayu, sehingga terjadi liberasi granula pati. Enzim-enzim yang dihasilkan oleh mikroba BAL akan menghidrolisis pati yang terdapat pada umbi ubi kayu menjadi gula yang selanjutnya akan diubah menjadi asam-asam organik, terutama asam laktat. (Subagio, 2013).

Fermentasi pembuatan mocaf biasanya menggunakan BAL namun ada juga secara spontan (tanpa mikroba/isolat). Ubi kayu merupakan komoditi unggulan Sumatera Barat, sehingga dapat digunakan sebagai bahan baku pembuatan tepung mocaf dengan menggunakan isolat indigenous yang berasal dari ubi kayu lokal daerah tersebut. Jenis ubi kayu yang digunakan sebagai sumber bakteri indigenous adalah ubi kayu jenis lokal Sumatera Barat berupa ubi kayu jenis lambau dan ketan (Manihot esculenta Crantz) serta ubi kayu jenis karet (Manihot glaziovii)

Ubi kayu jenis lambau memiliki karakteristik pucuk daun bewarna hijau muda, dengan tangkai berwarna merah, warna batang coklat kemerahan serta memiliki cabang bewarna hijau kemerahan. Kulit luar umbi (periderm) bewarna coklat tua, warna kulit bagian dalam umbi (cortex) merah muda sedangkan daging umbi bewarna putih. Sedangkan ubi kayu jenis ketan memiliki pucuk daun bewarna hijau kecoklatan, tangkai daun bewarna hijau kemerahan, daun dewasa bewarna hijau tua, tangkai daun bewarna hijau kemerahan, permukaan batang bewarna coklat, kulit luar umbi (periderm) bewarna coklat tua, kulit bagian dalam (korteks) umbi bewarna krem dan daging umbi bewarna putih (Firdaus et al., 2016).

Ubi kayu kultivar karet (Manihot glaziovii) merupakan ubi kayu jenis pahit yang berasal dari Brazil.
Pemanfaatan ubi kayu kultivar karet jarang dimanfaatkan dalam kehidupan sehari-hari karena rasanya yang pahit. Ubi kayu jenis ini memiliki ukuran umbi yang besar dengan kandungan karbohidrat yang tinggi sehingga cukup baik sebagai makanan sumber energi. Ubi kayu kultivar karet selain mengandung karbohidrat juga mengandung sianida yang dapat menghambat kerja enzim pernafasan sehingga terjadi gangguan pernafasan yang dapat menyebabkan sakit sampai kematian (Suprapti, 2005).

Bakteri indigenous merupakan bakteri pengurai yang hidup bebas di alam dan memiliki berbagai macam manfaat yang dapat digunakan sebagai pendukung teknologi pangan ataupun pertanian di bidang mikrobiologi. Bakteri ini merupakan bakteri lokal yang secara alami ada pada suatu ekosistem contohnya pada buah tapi tidak aktif saat pertumbuhan tanaman terjadi dan akan tumbuh pada saat proses pematangan buah atau proses enzimatis. Bakteri indigenous dapat diperoleh dengan cara mengisolasi bakteri tertentu pada suatu bahan yang mengandung gula (sukrosa, heksosa, pentosa) dan keberadaan bakteri ini dapat dilihat secara in vitro baik secara mikroskopis maupun makroskopis melalui media-media spesifik (Mokoena et al., 2016; Nurmalinda et al., 2013).

Isolat bakteri indigenous yang didapatkan dari isolasi ubi kayu jenis lambau, ketan dan ubi kayu karet termasuk dalam golongan bakteri asam laktat (BAL) (Kamsina et al., 2016; Riza, 2015; Rizki, 2016) Penggunaan BAL indigenous sebagai starter pada proses fermentasi mocaf dimaksudkan agar BAL tersebut mampu tumbuh optimum selama proses fermentasi, dikarenakan bakteri tersebut tidak memerlukan adaptasi selama proses fermentasi karena sudah terbiasa dengan lingkungan asli hidupnya seperti kondisi lingkungan yang asam dan sumber karbon yang berasal dari ubi kayu (Suseno et al., 2016) Berdasarkan hal tersebut, maka dilakukan penelitian mengenai pengaruh jenis isolat-isolat bakteri fermentatif dari ubi kayu terhadap rendemen, derajat putih dan bentuk granula tepung mocaf. Tujuan penelitian ini adalah untuk melihat kemampuan masing-masing isolat bakteri indigenous dari ubi kayu dalam proses fermentasi pembuatan tepung mocaf yang dibandingkan dengan perlakuan tanpa pemberian isolat.

\section{Metode}

Penelitian dilakukan di Balai Riset dan Standardisasi Industri Padang dan Laboratorium Mikrobiologi Jurusan Biologi Fakultas Matematika dan Ilmu Pengetahuan Alam Universitas Andalas Padang.

Bahan utama yang diperlukan adalah ubi kayu jenis lambau, isolat bakteri asam laktat yaitu: isolat bakteri indigenous ubi kayu jenis lambau (Rizki, 2016), ketan (Riza, 2015) dan kultivar karet (Kamsina et al., 2016), medium glucose peptone agar (GPA), kalsium karbonat $\left(\mathrm{CaCO}_{3}\right)$, medium agar pati beras (APB), medium carboxy methyl cellulose (CMC), medium skim milk 
agar (SMA), ethanol 70\%, larutan spiritus, larutan $\mathrm{H}^{2} \mathrm{O}^{2}$, aquadest, set pewarnaan gram, kertas saring, kapas, kain kasa, plastik, aluminium foil, tissu, plastik wrap, masker, dan sarung tangan dan bahan kimia untuk pengujian.

Peralatan yang digunakan adalah autoklaf, oven, neraca, cawan petri, tabung reaksi, pipet ukur, erlenmeyer, jarum ose, batang pengaduk, lampu spiritus, rak tabung reaksi, gelas piala, gelas ukur, spektofotometer, sprayer, kaca objek, cover glass, corong, pipet tetes, hot plate, vortex, magnetic stirer, inkubator, timbangan digital, kulkas, colony counter, sentrifuse, mikropipet, $\mathrm{pH}$ meter digital, mikroskop, oven, sealer, pengering vakum dan peralatan untuk pengujian.

Penelitian menggunakan rancangan acak lengkap (RAL) dengan 4 (empat) perlakuan yaitu (A) pemberian starter isolat bakteri indigenous ubi kayu jenis ketan; (B) ubi kayu jenis lambau; (C) ubi kayu varietas karet dan (D) tanpa isolat.

\subsection{Pembuatan tepung mocaf}

Proses pembuatan tepung ubi kayu termodifikasi (mocaf) mengikuti urutan sebagaimana tercantum dalam Gambar 1.

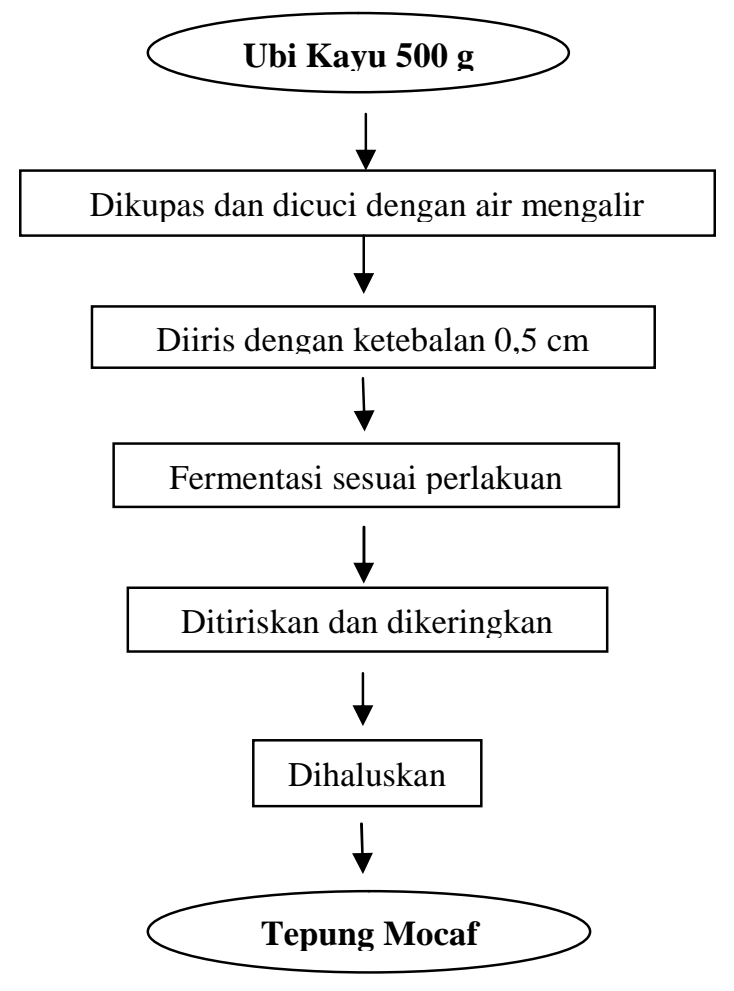

Gambar 1. Diagram alir proses pembuatan tepung mocaf

\subsection{Analisis}

Analisis yang dilakukan terhadap pembuatan tepung mocaf meliputi:

\subsubsection{Rendemen}

Rendemen di peroleh dari jumlah kilogram produk yang terbentuk dari setiap kilogram bahan yang diolah seperti rumus (1) (Amanu and Susanto, 2014).

$$
\text { Rendemen }=\frac{\text { berat produk yang dihasilkan (gram) x100\% }}{\text { Berat bahan baku (gram) }}
$$

\subsubsection{Derajat putih}

Pengukuran derajat putih dilakukan dengan chromameter yang dikalibrasi dengan standard warna putih lalu tepung dimasukkan ke dalam kuvet (Ariyantoro et al., 2016). Selanjutnya diukur nilai L, a dan $\mathrm{b}$ dan dihitung derajat putih dengan rumus (2)

$$
\mathrm{W}(\%)=100-\left[\left(100-\mathrm{L}^{*}\right)^{2}+\mathrm{a}^{*^{2}}+\mathrm{b}^{*^{2}}\right]^{1 / 2}
$$

\section{Keterangan:}

L: warna hitam (0) sampai cerah/terang (100) L* adalah hitam (0) sampai cerah/terang (100)

a : warna merah $(60)$ sampai hijau $(-60)$

$\mathrm{b}$ : warna kuning (60) sampai biru (-60)

\subsubsection{Bentuk granula}

Karakterisasi struktur mikro sampel dilakukan menggunakan Scanning Electron Microscope (SEM) merek JEOL, tipe JED-2300 dengan spesifikasi karakterisasi : voltage $=20,0 \mathrm{kV}$ dan pixel $=512 \times 384$ (Husniati and Adi, 2010).

\section{Hasil dan pembahasan 3.1. Rendemen}

Hasil analisis uji statistik terhadap rata-rata rendemen tepung mocaf dengan perlakuan pemberian starter dari beberapa jenis isolat bakteri indigenous ubi kayu dan pembanding didapatkan hasil yang berbeda nyata terhadap semua perlakuan yang dapat dilihat pada Gambar 2.

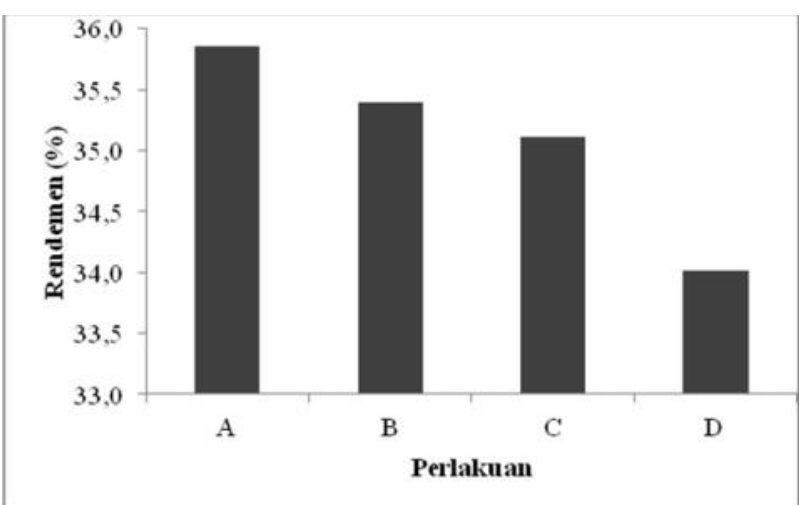

Gambar 2. Rendemen tepung mocaf pada perlakuan pemberian isolat bakteri indigenous ubi ketan (A), lambau (B), karet (C) dan control (D). 
Berdasarkan Gambar 2 dapat dilihat bahwa perlakuan pemberian isolat bakteri indigenous dari ubi ketan memberikan rendemen tertinggi yaitu $35,850 \%$ dari bobot ubi kayu yang diberikan yaitu sebanyak $500 \mathrm{~g}$ dan tidak berbeda dengan perlakuan pemberian isolat indigenous ubi lambau dan ubi karet, tetapi berbeda nyata dengan perlakuan tanpa pemberian isolate bakteri indigenous (D) dengan rendemen sebesar 34,012\%.

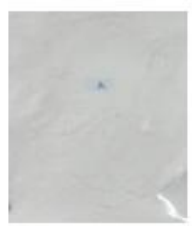

A

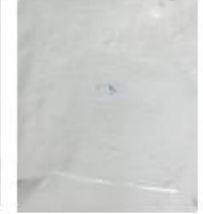

B

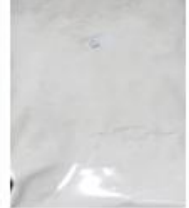

C

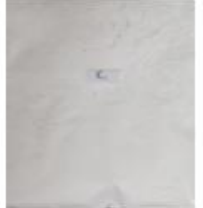

D
Gambar 3. Foto tepung mocaf dengan beberapa perlakuan isolat bakteri indigenous ubi ketan (A), lambau (B), karet (C) dan kontrol (D).

Berbedanya rendemen yang didapat pada perlakuan yang menggunakan isolat dengan tanpa isolat disebabkan oleh aktivitas mikroba pada proses fermentasi tepung mocaf. Selama proses fermentasi terjadi peningkatan jumlah mikroba yang memanfaatkan bahan organik sebagai sumber energi. Selain itu jenis atau varietas dari ubi kayu yang berbeda juga dapat berpengaruh terhadap rendemen tepung mocaf yang dihasilkan. (Amanu and Susanto, 2014). Perlakuan pemberian isolat bakteri indigenous dari ubi ketan memberikan rendemen yang terbaik dengan rendemen tepung mocaf sebesar $180 \mathrm{~g}$ per $500 \mathrm{~g}$ irisan ubi kayu $(35,850 \%)$. Selain itu, besarnya rendemen dipengaruhi oleh tahapan proses, seperti perajangan, jenis dan suhu pengering, penepungan, serta pengayakan, yang semuanya dapat meningkatkan kehilangan berat tepung yang dihasilkan. Rendemen merupakan presentase produk yang didapatkan dari membandingkan berat awal bahan dengan berat akhirnya sehingga dapat di ketahui kehilangan beratnya pada proses pengolahan (Nurdyansyah et al., 2018). Selain itu jenis varietas yang berbeda dapat berpengaruh terhadap rendemen yang dihasilkan (Amanu and Susanto, 2014).

\subsection{Derajat putih}

Hasil analisis derajat putih tepung dari perlakuan pemberian isolat bakteri indigenous dari beberapa jenis ubi kayu kayu, dapat dilihat pada Gambar 4. Derajat putih tepung mocaf dari perlakuan pemberian isolat bakteri indogenous ubi kayu jenis ketan (A) memberikan nilai yang tertinggi sebesar 94,40 dan diikuti oleh perlakuan C (ubi kayu varietas karet), dan yang terendah dengan perlakuan tanpa pemberian isolate (D) dengan nilai 92,66 . Derajat putih tepung mocaf dari beberapa perlakuan ini menurut SNI 01-7622-2011 (Tepung Mocaf) semuanya memenuhi stadar dengan nilai minimal 87\% (Badan Standardisasi Nasional, 2011).

Berbedanya nilai derajat putih tepung mocaf yang diperlakukan dengan penambahan isolat bakteri asam laktat (BAL) dan tanpa BAL, berpengaruh terhadap nilai derajat putih tersebut. Hal ini disebabkan dengan adanya aktivitas BAL yang dapat menghambat aktiivitas enzim fenolase yaitu enzim yang menyebabkan warna kecoklatan, sehingga derajat putih pada tepung mocaf meningkat. Proses fermentasi juga dapat menghilangkan komponen penimbul warna dan protein dan dapat menyebabkan warna putih. Pemberian bakteri asam laktat pada proses fermentasi dapat menghasilkan tepung dengan tekstur yang lembut dan warna tepung lebih putih dibandingkan tepung tanpa isolat BAL. Selain itu nilai derajat putih pada suatu bahan dapat dipengaruhi oleh beberapa faktor, seperti reaksi pencoklatan enzimatis, reaksi Maillard, reaksi karamelisasi, dan pigmen alami yang terdapat dalam bahan tersebut. (Ariyantoro et al., 2016; Lopulalan et al., 2016; Meryandini et al., 2019).

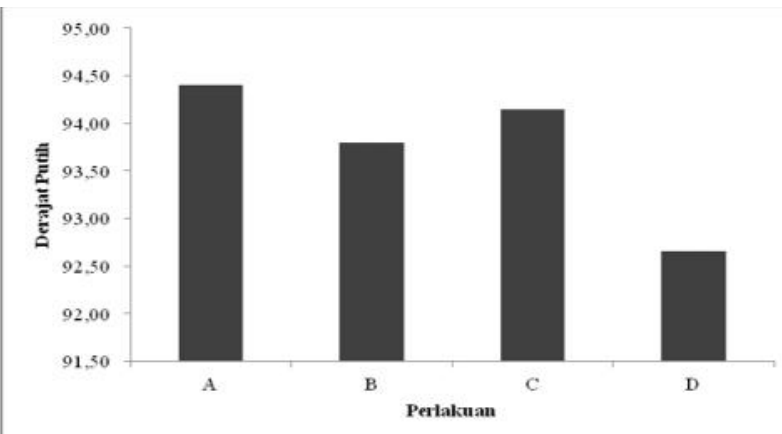

Gambar 4. Derajat putih tepung mocaf pada perlakuan pemberian isolat bakteri indigenous indigenous ubi ketan (A), lambau (B), karet (C) dan kontrol (D).

\subsection{Bentuk granula}

Analisis bentuk granula dari tepung mocaf dengan pengamatan Scanning Electron Microscope (SEM) ini adalah hasil pengamatan struktur mikro sampel dengan menggunakan SEM. Hasil dari pengamatan ini terlihat seperti yang ditunjukkan pada Gambar 5.

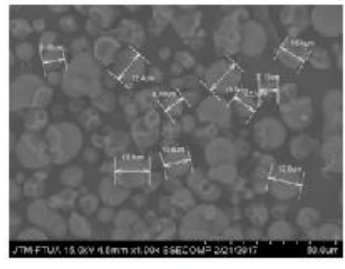

a

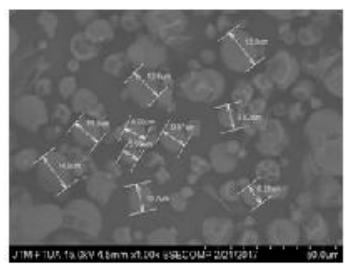

c
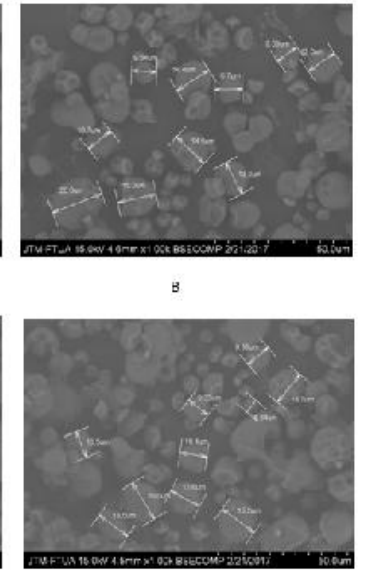

4
Gambar 5. Bentuk granula tepung mocaf pada perlakuan pemberian isolat bakteri indigenous ubi ketan (A), lambau (B), karet (C) dan kontrol (D).

SEM merupakan teknik yang sangat handal untuk menguji dan menganalisis struktur/morfologi/ bentuk dari matrik pada skala mikro/nano. SEM adalah salah satu jenis mikroskop elektron yang menggunakan berkas 
elektron untuk menggambarkan bentuk permukaan dari material yang dianalisis

Berdasarkan Gambar 5 terlihat bahwa perlakuan pemberian isolat BAL indigenous dari beberapa jenis ubi kayu dibandingkan dengan pembanding (tanpa isolat) memperlihatkan perbedaan perubahan struktur pati. Pada perlakuan pemberian isolat bakteri indogenous ubi kayu jenis ketan (A), dapat dilihat bahwa dinding sel ubi kayu sudah banyak yang pecah menjadi granula-granula yang lebih kecil dan memiliki rongga pada bagian granulanya. Pada perlakuan isolat ubi ketan ukuran granula berkisar antara $8,48 \mu \mathrm{m}-13,3 \mu \mathrm{m}$ dengan rongga-rongga pada semua granula serta memiliki granula-granula yang pecah, sehingga dapat menyebabkan liberasi granula pati terus berlanjut. Hal ini membuat tekstur dari tepung mocaf yang dihasilkan menjadi lembut. Sementara itu pada pemberian isolat ubi lambau (B) dan karet (C), meskipun granulamya sudah memiliki rongga namun belum banyak granulanya yang pecah. Perlakuan kontrol (D) walaupun granulanya berukuran 5,64 $\mu \mathrm{m}-16,0 \mu \mathrm{m}$, namun rongga-rongga pada granulanya masih sedikit. Dalam hal ini terlihat bahwa perlakuan pemberian isolat bakteri indigenous berpengaruh terhadap bentuk granula yang tidak lagi halus (berlubang/bergerigi) dan bentuk bulat tidak beraturan . (Kartikasari et al., 2016; Yeni et al., 2018).

Bentuk granula pati ubi kayu terfermentasi yang memiliki permukaan tidak rata dengan gerigi/lubang yang dangkal berdiameter cukup besar ini diduga akibat terhidrolisis oleh amilase maupun asam organik. Asam ini dapat berasal dari aktivitas bakteri asam laktat dan memiliki peran dalam perubahan granula pati (Widyatmoko et al., 2018). Penggunaan isolat bakteri asam laktat dapat memperbaiki swelling power dan tingkat pengembangan tepung ubi kayu dibanding dengan fermentasi tanpa bakteri. Mikroba yang tumbuh pada ubi selama proses fermentasi akan menghasilkan enzim pektinolitik dan selulolitik yang dapat menghancurkan dinding sel umbi ubi kayu sehingga terjadi pembebasan granula pati dan mendegradasi amilosa menjadi senyawa yang lebih sederhana yaitu glukosa. Hal ini mengakibatkan air yang terikat pada proses rehidrasi semakin banyak dan menyebabkan granula pati semakin membengkak dan mengembang sehingga terbentuk rongga-rongga pada sel (Kusumaningrum and Sumardiono, 2016).

\section{Kesimpulan}

Penggunaan isolat bakteri indigenous ubi kayu sangat potensial dibandingkan dengan perlakuan tanpa penggunaan isolat (kontrol) dalam pembuatan tepung mocaf. Parameter pengujian derajat putih untuk semua perlakuan memenuhi standar SNI 01-7622-2011 (Tepung Mocaf) dengan nilai minimal 87\%. Namun dalam penelitian ini pemberian isolat ubi ketan lebih optimal dengan analisis statistik berpengaruh terhadap perlakuan lainnya yang meliputi pengujian terhadap rendemen $35,850 \%$, derajat putih $94,40 \%$, sedangkan untuk bentuk granulanya memiliki rongga-rongga yang cukup besar serta memiliki granula-granula yang sudah mulai pecah.

\section{Ucapan terima kasih}

Terima kasih diucapkan kepada rekan-rekan Elya Rovina, Silfia dan Firdausni yang telah ikut berperan selama penelitian sehingga penelitian dapat berjalan baik dan lancar.

\section{Daftar pustaka}

Amanu, F.N., Susanto, W.H., 2014. Pembuatan tepung mocaf di madura (kajian varietas dan lokasi penanaman) terhadap mutu dan rendemen. J. Pangan dan Agroindustri 2, 161-169.

Ariyantoro, A.R., Rachmawanti, D., Ikarini, I., 2016. Karakteristik fisikokimia tepung koro pedang (Canavalia ensiformis) termodifikasi dengan variasi konsentrasi asam laktat dan lama perendaman. Agritech 36, 1-6.

Badan Standardisasi Nasional, 2011. Tepung mokaf. SNI 7622-2011.

BPS Sumatera Barat, 2018. Badan Pusat Statistik Provinsi Sumatera Barat.

Firdaus, N.R., Hayati, P.D., Yusniwati, 2016. Karakterisasi fenotipik ubi kayu (Manihot esculenta Crantz) lokal Sumatera Barat. J. Agroteknologi 10.

Husniati, Adi, W.A., 2010. Analisis fasa dan strukturmikro pada tepung tapioka dengan penambahan natrium metabisulfit. J. Sains Mater. Indones. 13, 83-89.

Kamsina, Nurmiati, Periadnadi, 2016. Karakteristik bakteri indigenous dari ubi kayu karet (Manihot glaziovii) sebagai isolat dalam proses mocaf, in: Seminar Nasional Hasil Riset Dan Standardisasi Industri VI. Balai Riset dan Standardisasi Industri Banda Aceh, Banda Aceh, pp. 108-117.

Kartikasari, S.N., Sari, P., Subagio, A., 2016. Karakterisasi sifat kimia, profil amilografi (rva) dan morfologi granula (sem) pati singkong termodifikasi secara biologi. J. Agroteknologi 10.

Kusumaningrum, A., Sumardiono, S., 2016. Perbaikan sifat tepung ubi kayu melalui proses fermentasi sawut ubi kayu dengan starter bakteri asam laktat. J. Apl. Teknol. Pangan 5, 31-33. https://doi.org/10.17728/ jatp. 8

Lopulalan, C.G.C., Mailoa, M., Pelu, H., 2016. Analisa sifat kimia dan fisik modified cassava flour (mocaf) (varietas lokal sangkola) asal desa waai, Maluku Tengah. AG R I TE KNO, J. Teknol. Pertan. 5, 712. https://doi.org/10.30598/jagritekno.2016.5.1.7

Meryandini, A., Melani, V., Sunarti, T.C., 2019. Addition of cellulolytic bacteria to improved the quality of fermented cassava flour. African J. Food Sci. Technol.

Mokoena, M.P., Mutanda, T., Olaniran, A.O., 2016. Perspectives on the probiotic potential of lactic acid bacteria from African traditional fermented foods and beverages. Food Nutr. Res. 60, 29630. https://doi.org/10.3402/fnr.v60.29630

Nurdyansyah, F., Hafidz, U., Hasbullah, A., 2018. Optimasi fermentasi asam laktat oleh Lactobacillus casei pada media fermentasi yang disubtitusi tepung kulit pisang. J. Biol. 11, 64-71. 
Nurmalinda, A., Periadnadi, Nurmiati, 2013. Isolasi dan karakterisasi parsial bakteri indigenous pemfermentasi dari buah durian (durio zibethinus murr.) Isolation and partial characterization of indigenous fermenting bacteria from durian fruit (durio zibethinus murr.). Biol. Univ. Andalas 2, 813.

Putri, S.W.A., Hersoelistyorini, W., 2012. Kajian kadar protein, serat, hcn, dan sifat organoleptik prol tape singkong dengan substitusi tape kulit singkong. J. Pangan dan Gizi 03.

Riza, Y., 2015. Isolasi dan karakterisasi mikroflora indigenous pemfermentasi pada ubi kayu jenis ketan untuk proses mocaf. Universitas Andalas.

Rizki, C., 2016. Isolasi dan karakterisassi bakteri indigenous pemfermentasi dari umbi ubi kayu kultivar lambau dalam pencarian isolat unggul untuk proses mocaf.

Saliem, H.P., Nuryanti, S., 2011. Perspektif ekonomi global kedelai dan ubikayu mendukung swasembada, in: Prosiding Seminar Hasil Penelitian Tanaman Aneka Kacang Dan Umbi 2011. pp. 1-14.

Subagio, A., 2013. Keunggulan mocaf sebagai bahan baku snack. Foodreview Indones. VOL. VIII, 38-40.

Suprapti, I.M.L., 2005. Teknologi pengolahan pangan tepung tapioka, pembuatan \& pemanfaatannya.

Suseno, D., Meryandini, A., Sunarti, T.C., 2016. Kinerja fermentasi sagu asam menggunakan starter cair dan padat dari isolat bakteri asam laktat indigenous. J. Teknol. Ind. Pertan. 26, 111-124.

Widyatmoko, H., Subagio, A., Nurhayati, N., 2018. Sifat-sifat fisikokimia pati ubi kayu terfermentasi khamir indigenus tapai. Agritech 38, 140-150.

Yeni, G., Silfia, S., Hermianti, W., Wahyuningsih, T., 2018. Pengaruh waktu hidrolisis dan konsentrasi $\mathrm{HCl}$ terhadap karakteristik pati termodifikasi dari bengkuang (Pachyrrhizus erosus). J. Litbang Ind. 8, 53-60. 